\title{
ANALISIS PELAYANAN KOPERASI CUBG TP.PAMULANG UNTUK MENINGKATKAN KEPUASAN ANGGOTA DENGAN METODE SERVQUAL DAN IMPORTANCE PERFORMANCE ANALYSIS (IPA)
}

\author{
Ernima gulo $^{* 1}$, Irvana arofah ${ }^{2}$, Ilmadi $^{3}$, Aden $^{4}$, Gerry sastro ${ }^{5}$ \\ 1,2,3,4,5Program Studi Matematika FMIPA Universitas Pamulang \\ ernygulo2@gmail.com*1 ${ }^{*}$,dosen00351@unpam.ac.id ${ }^{2}$, il.ilmadi@yahoo.com³ \\ dosen00527@unpam.ac.id ${ }^{4}$,dosen00544@unpam.ac.id ${ }^{5}$
}

\begin{abstract}
This research was conducted to achieve improving the quality of service to members, for this reason, a service quality analysis method is needed. Here the methods needed are Service Quality (Servqual) and Importance Performance Analysis (IPA) methods. The purpose of this study is to identify the level of customer satisfaction with service quality by the CUBG Tp Cooperative. Pamulang, to find out what aspects are supporting the improvement of service quality and to provide recommendations for improvements or revisions that are prioritized to improve service quality at the CUBG Tp Cooperative. Pamulang. This research method is quantitative descriptive analysis using Servqual and Importance Performance Analysis (IPA) methods. The results of this study are the level of satisfaction of cooperative members using the Customer Satisfaction Index (CSI) method with a percentage of 86.05\%. Based on the calculation of Servqual Analysis of 5 dimensions, namely Tangibility (physical evidence), Reliability (Reliability), Responsiveness (Awareness / responsiveness), Assurance (Guarantee) and Empathy (Empathy) represented by 25 attributes obtained if members of the CUBG Cooperative TP.Pamulang have been satisfied with the Servqual provided by the CUBG Cooperative Tp.Pamulang, this is shown in the average gap between expectations and reality of 0.05 .
\end{abstract}

Keywords: Quality of Service, Servqual Methods,and Importance Performance Analysis (IPA).

\begin{abstract}
Abstrak
Penelitian ini dilakukan untuk Menggapai tingkatkan kualitas pelayanan terhadap anggota, untuk itu dibutuhkan metode analisa kualitas jasa pelayanan. Disini metode yang dibutuhkan merupakan Metode Service Quality (Servqual) dan Importance Performance Analysis (IPA). Tujuan penelitian ini yaitu untuk mengengali tingkatan kepuasan konsumen terhadap kualitas pelayanan oleh Koperasi CUBG Tp. Pamulang, untuk mengetahui aspek apa saja yang jadi penunjang dalam perbaikan kualitas pelayanan serta untuk memberikan usulan perbaikan atau revisi yang diprioritaskan untuk meningkatkan kualitas pelayanan pada Koperasi CUBG Tp. Pamulang. Metode penelitian ini ialah analisis deskriptif kuantitatif dengan memakai metode Servqual dan Importance Performance Analysis (IPA). Hasil dari penelitian ini merupakan tingkatan kepuasan anggota koperasi menggunakan metode Customer Satisfaction Index (CSI) dengan persentase 86,05\%. Bersumber pada perhitungan Analisis Servqual dari 5 dimensi ialah Tangibility (Bukti fisik), Reliability (Kehandalan), Responsiveness (Kesinggapan/ daya tanggap), Assurance (Jaminan) dan Emphaty (Empati) yang diwakilkan oleh 25 atribut didapatkan jika anggota Koperasi CUBG TP.Pamulang telah puas terhadap Servqual yang diberikan oleh Koperasi CUBG Tp.Pamulang, perihal ini ditunjukkan pada rata-rata Gap harapan serta kenyataan sebesar 0,05. Kata kunci: Kualitas Pelayanan, Metode Servqual, Importance Performance Analysis (IPA).
\end{abstract}


Jurnal Lebesgue : Jurnal Ilmiah Pendidikan Matematika, Matematika dan Statistika

Ernima Gulo, Irvana arofah, Ilmadi, Aden, Gerry sastro

Volume 2, No. 2, Agustus 2021 hal.145-152

DOI Artikel : 10.46306/lb.v2i2.61

\section{PENDAHULUAN}

Berdasarkan persaingan dalam perkembangan manajemen keuangan yang sangat pesat pada saat ini yang ada dalam dunia bisnis secara khusus untuk koperasi. Banyak koperasi baru yang bermunculan, namun tidak sedikit pula perusahaan yang harus begitu saja menyerah untuk mengakhiri dalam berbisnis ataupun mempertahankan usahanya. Didalam tingkatan persaingan, setiap perusahaan wajib bisa memenangkan persaingan tersebut dengan penuhi kepuasan konsumen yang senantiasa berkembang dan berubah-ubah, hingga perusahaan wajib mampu memberikan pelayanan yang optimal terhadap konsumen. Koperasi ini salah satu tipe koperasi yang bergerak dalam jasa keuangan yang melaksanakan usahanya dengan metode menghimpun serta dalam wujud tabungan, deposito serta menyalurkannya dengan prosedur yang mudah dan cepat.

Koperasi simpan pinjam memegang peranan penting selaku alternative lembaga keuangan yang efisien untuk menjangkau golongan usaha mikro, kecil serta menengah. Salah satu tempat pelayanan yang bergerak dibidang penawaran simpan pinjam, Koperasi Cubg Tp. Pamulang senantiasa berupaya memberikan pelayanan yang baik kepada setiap anggota. Bila anggota koperasi yang telah bergabung merasa puas pastinya hendak akan bersinambungan, hingga hal ini merupakan asset yang sangat berharga bagi koperasi. Namun bila terdapat anggota yang merasa tidak puas, bisa dalam hal pelayanan yang kurang memuaskan, hingga hal ini hendak menimbulkan kehilangan atensi anggota untuk melakukan aktivitas simpanan, pinjaman, serta menimbulkan anggota memiliki pemikiran negatif terhadap koperasi tersebut, dampaknya jumlah anggota hendak hadapi penyusutan. Hingga dari itu, Koperasi butuh mencari metode untuk meningkatkan sistem palayanan yang baik dan memuaskan untuk anggotanya supaya dapat mempertahankan jumlah anggota dan supaya dapat menaikkan atensi orang lain untuk turut bergabung.

Oleh karena itu, Butuh dicarikan pemecahan dan dicoba dianalisis, supaya terlihat aspek apa yang membuat anggota kurang puas dengan pelayanan yang diberikan oleh koperasi. Untuk menggapai kepuasan anggota dibutuhkan adanya pelayanan yang baik disamping factor-faktor lain yang melekat pada sifat jasa itu sendiri. Untuk meningkatkan kualitas pelayanan terhadap anggota, dibutuhkan metode analisa kualitas jasa pelayanan. Disini metode yang digunakan merupakan Metode Service Quality (Servqual) dan IPA. Dengan tata cara ini kita bisa mengetahui kesenjangan (GAP) yang terjalin antara persepsi anggota dengan harapan/keinginan dengan menempatkan dalam dimenssi pelayanan, dimana: bukti fisik (tangibel), dimensi kehandalan (reability), dimensi daya tanggap (responsiveness), 
dimensi jaminan (assurance) serta dimensi empati (emphaty). Metode servqual digunakan buat mengenali kebutuhan anggota serta kesuksesan layanan yang diberikan industri. Metode servqual serta IPA digunakan untuk menyusun strategi baru dalam membagikan pelayanan yang optimal kepada pelanggan.

\section{METODE PENELITIAN}

Metode penelitian adalah suatu cara ilmiah yag digunakan untuk mendapat data dengan tujuan tertentu. Menurut Supangat (2013:2) data adalah bentuk jamak dari datum, yang dapat diartikan sebagai informasi yang diterima yang bentuknya dapat berupa angka, kata-kata, atau dalam bentuk lisan dan tulisan lainnya Dalam penelitian ini peneliti menggunakan metode kuantitatif dengan data primer. Teknik pengumpulan data yang digunakan dalam penelitian ini adalah diperoleh melalui kuesioner yaitu suatu metode pengumpulan data primer yang memerlukan adanya komunikasi antara peneliti dan responden dengan memberikan pertanyaan-pertanyaan kepada responden yang ada pada kuesioner. Penelitian ini dilaksanakan di Kantor Cabang CUBG TP. Pamulang. Populasi dalam riset ini ialah semua anggota CUBG (Credit Union Bererod Gratia) TP. Pamulang sebanyak 1.572 orang. Selain itu, jumlah sampel bisa ditentukan dengan mengarah pada pendekatan rumus Slovin (Umar, 2012), yaitu 95 responden.

Metode Pengumpulan data yang dicoba dalam riset ini memakai metode kuesioner serta dokumentasi. Instrumen riset yang digunakan berbentuk angket dengan mendapatkan data yang relefan dengan tujuan survey. Kuesioner berisi 25 persoalan yang adalah penjabaran dari 5 dimensi kualitas pelayanan tipe servqual, ialah kehandalan/reliability, daya tanggap/responsiveness, jaminan/assurance, empati/emphaty, bukti fisik/tangible. Dari 25 persoalan kuesioner tersebut responden dimohon buat membagikan evaluasi hendak tingkatan kepuasan kualitas pelayanan Koperasi cubg pamulang.

Dalam Riset ini metode yang digunakan merupakan Metode Service Quality (Servqual) dan Importance Performance Analysis (IPA). Pelaksanaan tatacara Servqual dan IPA dalam pengukuran kesenjangan ialah buat mengenali kekuatan serta kelebihan pada industri jasa. Dengan tatacara ini kita bisa mengenali kesenjangan (GAP) yang terjalin antara persepsi anggota dengan harapan/keinginan dengan menempatkan dalam ukuran pelayanan, dimana: bukti fisik (tangibel), dimensi kehandalan (reability), dimensi daya tanggap (responsiveness), dimensi jaminan (assurance) serta dimensi empati (emphaty). 
Jurnal Lebesgue : Jurnal Ilmiah Pendidikan Matematika, Matematika dan Statistika

Ernima Gulo, Irvana arofah, Ilmadi, Aden, Gerry sastro

Volume 2, No. 2, Agustus 2021 hal.145-152

DOI Artikel : 10.46306/lb.v2i2.61

\section{HASIL DAN PEMBAHASAN}

\section{Hasil Nilai GAP dan RANK}

Tabel 5. Hasil Nilai Gap dan Rank

TABEL : RANK GAP

\begin{tabular}{|c|c|c|c|}
\hline NO & ATRIBUT & GAP & RANK \\
\hline 1 & $\begin{array}{l}\text { Kerapian dan kebersihan ruangan koperasi CUBG cukup } \\
\text { terjaga (tersedia tempat sampah) }\end{array}$ & $-0,116$ & 21 \\
\hline 2 & $\begin{array}{l}\text { Karyawan Koperasi CUBG menggunakan pakaian yang rapi } \\
\text { dan sopan }\end{array}$ & $-0,126$ & 23 \\
\hline 3 & $\begin{array}{l}\text { Tersedia air minum untuk anggota yang menunggu diruang } \\
\text { tunggu }\end{array}$ & 0,095 & 9 \\
\hline 4 & $\begin{array}{l}\text { Koperasi CUBG pamulang selalu memperhatikan kerapian } \\
\text { dalam penataan fasilitas, misalnya susunan kursi diruang } \\
\text { tunggu bersih dan rapih. }\end{array}$ & 0,347 & 2 \\
\hline 5 & Area parkir luas dan aman & $-0,011$ & 16 \\
\hline 6 & Area parkir tergaja kebersihannya dan kerapiannya & $-0,084$ & 20 \\
\hline 7 & $\begin{array}{l}\text { Waktu buka dan tutup Koperasi CUBG Pamulang Tepat } \\
\text { Waktu }\end{array}$ & 0,042 & 12 \\
\hline 8 & $\begin{array}{l}\text { Permintaan Pinjaman uang dapat dipenuhi oleh koperasi } \\
\text { sesuai harapan anggota }\end{array}$ & 0,053 & 11 \\
\hline 9 & $\begin{array}{l}\text { Koperasi memberikan alur pengajuan pinjaman yang mudah } \\
\text { bagi anggota }\end{array}$ & $-0,242$ & 25 \\
\hline 10 & $\begin{array}{l}\text { Koperasi memberikan alur pengajuan simpanan yang mudah } \\
\text { bagi anggota }\end{array}$ & 0,011 & 15 \\
\hline 11 & $\begin{array}{l}\text { Karyawan Koperasi CUBG selalu berada didalam ruangan } \\
\text { ketika anggota butuhkan }\end{array}$ & 0,084 & 10 \\
\hline 12 & $\begin{array}{l}\text { Pengajuan pinjaman uang diproses dengan cepat dan sesuai } \\
\text { dengan prosedur koperasi }\end{array}$ & 0,284 & 3 \\
\hline 13 & $\begin{array}{l}\text { Proses pengambilan simpanan sukarela anggota, tidak } \\
\text { membutuhkan waktu yang lama }\end{array}$ & 0,232 & 4 \\
\hline 14 & $\begin{array}{l}\text { Koperasi selalu memberikan sosialisasi dengan optimal } \\
\text { mengenai pentingnya berkoperasi dan manfaat koperasi bagi } \\
\text { anggota }\end{array}$ & 0,137 & 7 \\
\hline 15 & $\begin{array}{l}\text { Karyawan Koperasi CUBG terampil dan kompeten dalam } \\
\text { bidangnya }\end{array}$ & $-0,168$ & 24 \\
\hline 16 & $\begin{array}{l}\text { Karyawan Koperasi CUBG memiliki pengetahuan menjawab } \\
\text { pertanyaan seputar prosedur simpan pinjam yang tidak } \\
\text { dimengerti anggota }\end{array}$ & $-0,116$ & 22 \\
\hline 17 & $\begin{array}{l}\text { Prosedur simpanan dan pinjaman yang diberikan Koperasi } \\
\text { CUBG, membuat anggota yang menabung atau melakukan } \\
\text { pinjaman dikoperasi, merasa aman }\end{array}$ & $-0,032$ & 17 \\
\hline 18 & Keamanan area parkir di koperasi CUBG cukup terjaga & $-0,042$ & 18 \\
\hline
\end{tabular}


Jurnal Lebesgue : Jurnal Ilmiah Pendidikan Matematika, Matematika dan Statistika

Ernima Gulo, Irvana arofah, Ilmadi, Aden, Gerry sastro

Volume 2, No. 2, Agustus 2021 hal.145-152

DOI Artikel : 10.46306/lb.v2i2.61

\begin{tabular}{|c|l|c|c|}
\hline 19 & $\begin{array}{l}\text { Pelayanan karyawan Koperasi CUBG yang selalu sopan dan } \\
\text { ramah, membuat anggota merasa nyaman }\end{array}$ & 0,032 & 14 \\
\hline 20 & $\begin{array}{l}\text { Karyawan koperasi CUBG bersedia mencermati keluhan } \\
\text { saya serta menanggapinya dengan sopan dan baik }\end{array}$ & $-0,074$ & 19 \\
\hline 21 & $\begin{array}{l}\text { Karyawan akan menunjukkan kesungguhan dalam } \\
\text { menanggapi keluhan }\end{array}$ & 0,042 & 13 \\
\hline 22 & $\begin{array}{l}\text { Karyawan Koperasi menginformasikan prosedur simpan } \\
\text { pinjam dengan jelas dan mudah dimengerti oleh anggota }\end{array}$ & 0,400 & 1 \\
\hline 23 & $\begin{array}{l}\text { Karyawan koperasi CUBG minta maaf apabila pelayanan } \\
\text { melewati waktu yang dijanjikan }\end{array}$ & 0,200 & 5 \\
\hline 24 & $\begin{array}{l}\text { Karyawan koperasi melayani saya ketika ingin mengajukan } \\
\text { simpanan atau pinjaman dengan segera }\end{array}$ & 0,200 & 6 \\
\hline 25 & $\begin{array}{l}\text { Karyawan Koperasi selalu menyambut / menyapa anggota, } \\
\text { ketika anggota datang dan pergi }\end{array}$ & 0,105 & 6 \\
\hline
\end{tabular}

\section{Diagram Cartesius dari keseluruhan dimensi servqual}

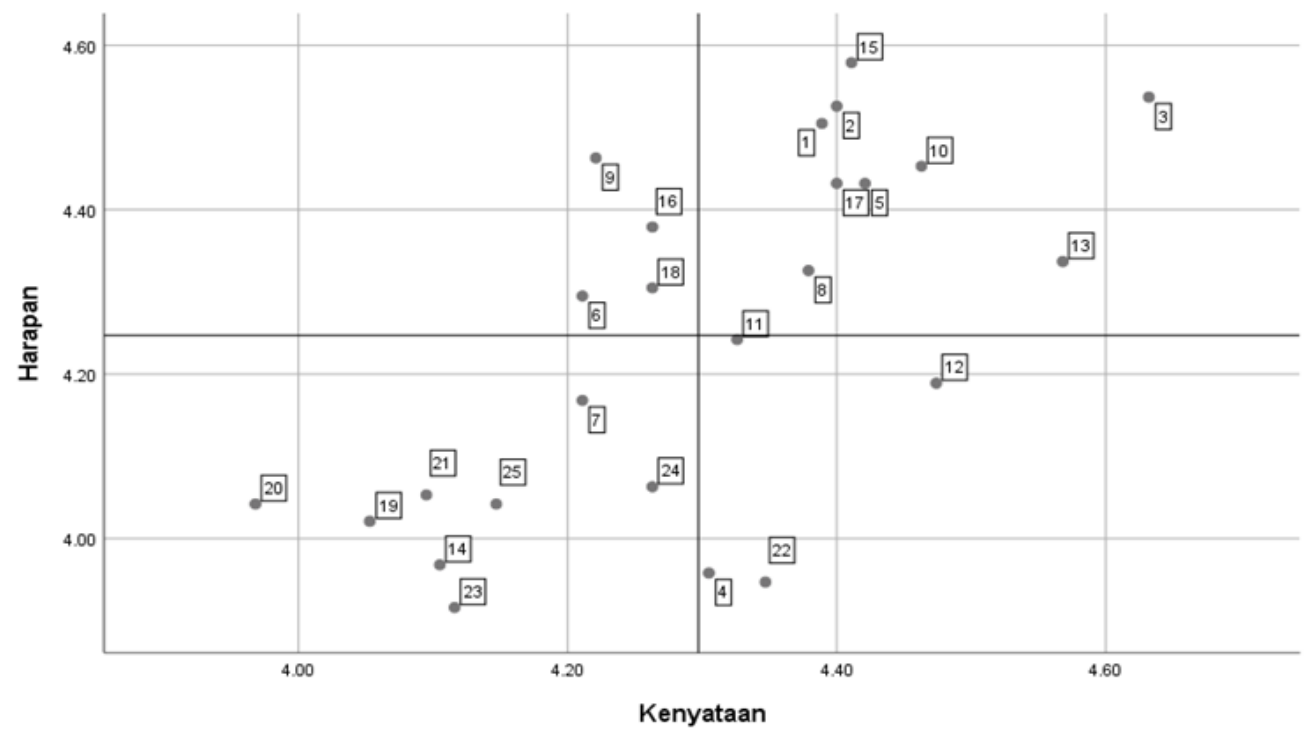

Gambar 1. Grafik Diagram Cartesius Dari Keseluruhan Dimensi Servqual

Pada penelitian ini diperlukan dimensi untuk menjadi sebuah parameter pengukur tentang service quality, pada penelitian ini yang digunakan oleh peneliti untuk menjadikan parameter ukuran service quality terdapat 5 jenis, yaitu Tangibility (Bukti fisik), Reliability (Kehandalan), Responsiveness (Kesinggapan/ daya tanggap), Assurance (Jaminan) dan Emphaty (Empati). Pada kelima dimensi tersebut mempunyai atribut-atribut yang mewakili dimensinya terdapat 25 atribut yang hendak diajukan kepada anggota koperasi. 
Seluruh atribut pernyataan yang diajukan kepada anggota koperasi hendak diuji datanya memakai uji validitas serta uji reliabilitas untuk menampilkan apakah data tersebut valid dan reliabel atau tidak. Bersumber pada hasil uji validitas serta reliabilitas dinyatakan bahwa keseluruhan data dari anggota koperasi valid dan reliable, sehingga bisa digunakan dalam perhitungan Service Quality dan importance Performance Analysis (IPA).

Bersumber dari pengolahan data Servqual yang sudah dicoba, berikutnya data tersebut hendak dilakukan analisis aspek yang menimbulkan adanya Gap antara kenyataan dan harapan, serta pemecahan perbaikan yang dapat dijadikan acuan dalam peningkatan Service Quality pada Koperasi CUBG Pamulang. Peningkatan kualitas perlu dilakukan mengingat hasil keseluruhan atribut servqual lumayan memiliki jarak dibanding dengan harapan anggota koperasi. Oleh sebab itu perbaikan pelayanan diharapkan bisa menjadi peningkatan kualitas pelayanan yang lumayan signifikan pada koperasi.

Metode Servqual untuk mengetahui nilai kesenjangan Gap dari dari masing-masing atribut yang mewakili tiap-tiap dimensi, setelah diketahuinya atribut yang mempunyai nilai Gap negative, hingga akan diberikan usulan perbaikan, tetapi usulan perbaikan dengan acuan perhitungan nilai Gap dari metode Servqual tidak bisa dilakukan sekaligus disebabkan membutuhkan waktu yang panjang dan bayaran yang besar. Oleh sebab itu dibutuhkan prioritas atribut yang perlu dicoba perbaikan bersumber pada bobot nyata terhadap kepuasan anggota koperasi. Salah satu metode untuk memastikan prioritas utama untuk dilakukan perbaikan ialah dengan menggunakan analisis IPA yang ditafsirkan pada diagram kartesius. Saat sebelum menampilkan hasil pada diagram, terlebih dulu mengenali tingkatan kinerja harapan yang diperoleh dari rata-rata masing-masing kinerja (X) serta rata-rata tingkatan kepentingan (Y), setelah itu, data tersebut dipaparkan dengan diagram Importance Performance Analysis (IPA), sehingga dikenal letak kuadrat masing-masing ukuran ataupun totalitas.

\section{KESIMPULAN}

Bersumber pada analisis kualitas pelayanan dengan memakai metode Service Quality serta Importance Performance Analysis (IPA) pada Koperasi CUBG Pamulang, hingga diperoleh kesimpulan antara lain : (a) Tingkat kepuasan anggota koperasi memakai metode Customer Satisfaction (CSI) dengan persentase 86,05\%. (b) Kelima faktor dimensi antara lain, terdapat : Tangibility (Bukti fisik), Reliability (Kehandalan), Responsiveness (Kesinggapan/ daya tanggap), Assurance (Jaminan) serta Emphaty (Empati), dengan bersumber pada hasil perhitungan analisis servqual bisa disimpulkan bahwa seluruh factor 
Jurnal Lebesgue : Jurnal Ilmiah Pendidikan Matematika, Matematika dan Statistika

Ernima Gulo, Irvana arofah, Ilmadi, Aden, Gerry sastro

Volume 2, No. 2, Agustus 2021 hal.145-152

DOI Artikel : 10.46306/lb.v2i2.61

tersebut yang diwakilkan oleh 25 atribut didapatkan mempunyai pengaruh yang signifikan terhadap anggota Koperasi CUBG Pamulang, perihal ini ditunjukkan pada rata-rata Gap harapan serta realitas sebesar 0,05. (c) Pada pengolahan analisis Importance Performance Analysis (IPA) atribut yang jadi prioritas utama untuk dikerjakan perbaikan pada Koperasi CUBG Pamulang totalitas Pada Kuadrat A, ialah Karyawan Koperasi CUBG terampil dan kompeten dalam bidangnya (15). pada kuadrat B, ialah Koperasi membagikan alur pengajuan pinjaman yang mudah untuk anggotanya (9). Pada Kuadrat B, ialah Karyawan Koperasi CUBG terampil dan kompeten dalam bidangnya (15). Pada Kuadrat C, ialah Karyawan koperasi CUBG bersedia mencermati keluhan saya serta menanggapinya dengan sopan dan baik (20). Pada Kuadrat D, ialah Karyawan Koperasi menginformasikan prosedur simpan pinjam dengan jelas serta mudah dipahami oleh anggota (22).

Pada penelitian yang sudah dicoba, hingga adanya saran yang direkomendasikan untuk Koperasi CUBG Pamulang, antara lain : (a) Hasil penelitian ini bisa digunakan sebagai referensi Koperasi CUBG Pamulang untuk mengetahui atribut pelayanan apa saja yang butuh diperbaiki dan atribut apa saja yang pelaksanannya sudah cocok dengan kepentingan serta penuhi harapan anggota koperasi. (b) Untuk membetulkan sebagian atribut negative pada penelitian ini yang wajib dicoba Koperasi CUBG pamulang ialah melaksanakan kesesuaian layanan serta keadaan fasilitas prasarana yang butuh ditingkatkan.

\section{DAFTAR PUSTAKA}

Alfatiyah, R. (2020). Analisis Kualitas Pelayanan Parkir Dengan Metode Servqual, Ipa serta Qfd Untuk tingkatkan Kepuasan Pelanggan Di Pt. Securindo Packatama Indonesia. JITMI (Jurnal Ilmiah Teknik serta Manajemen Industri), 2(2), 105-115.

Bekti, R.D., dkk. 2017. "Analisis Pengaruh Lokasi dan Karakteristik Konsumen Dalam Memilih Minimarket Dengan Metode Logistik dan CART”. Media Statistika VoI. 10 No. 2. 119-130.

Farminta, V., Mujiharjo, S., \& Susena, K. C. (2015). Analisis Kualitas Pelayanan Industri Jasa Olah Raga Dengan Menggunakan Metode Servqual dan Importence Performance Analysis (IPA). Program Studi Teknik Industri, Fakultas Teknik, Universitas Dahasen Bengkulu.

Kasiram. (2008). Metodologi Penelitian Kualitatis dan Kuantatif.

Lupioadi, Rambat dan A. Hamdani. 2006. Manajemen Pemasaran Jasa. (Jakarta: Salemba Empat.

Sinnun, A. (2017). Analisis Kepuasan Pengguna LMS Berbasis Web Dengan Metode Servqual, IPA dan CSI. Jurnal Informatika, 4(1).

Sugiyono, 2017. Statistika Untuk Penelitian. Bandung: Penerbit Alfabeta.

Sujarweni, V. Wiratna. 2014. Metodologi Penelitian: Lengkap, Praktis, dan Mudah dipahami. Yogyakarta: Pustaka Baru Press. 
Supangat, Andi. 2007. Statistika: Dalam Kajian Deskriptif, Inferensi, dan Nonparametrik. Jakarta: Kencana.

Sutrisno, S., Cahyono, D., \& Qomariah, N. (2017). Analisis Kualitas Pelayanan, Kepercayaan Serta Citra Koperasi Terhadap Kepuasan Dan Loyalitas Anggota. Jurnal Sains Manajemen Dan Bisnis Indonesia, 7(2).

Wilujeng, F. R., Rembulan, G. D., Andreas, D., \& Tannady, H. (2019). Meningkatkan Kepuasan Pelanggan pada Dua Bisnis E-Commerce Terbesar di Indonesia dengan Menggunakan Analisis Servqual dan IPA. Prosiding Semnastek.

Winarno, H., \& Absor, T. (2017). Analisis Kualitas Pelayanan Dengan Metode Service Quality (SERVQUAL) dan Importance Performance Analysis (IPA) Pada Pt. Media Purna Engineering. Jurnal Manajemen Industri dan Logistik, 1(2), 146-160.

Yamin, Sofyan, Heri Kurniawan. 2014. SPSS COMPLETE: Teknik Analisis Statistika terlengkap denganSoftware SPPS Edisi 2. Jakarta Selatan: Salemba Infotek.

Yusup, Febrianawati. 2018. "Uji Validitas dan Reabilits Instrumen Penelitian Kuantitatif". Jurnal Ilmiah Kependidikan Vol. 7 No.1. Januari - Juni (17-23). 